\title{
PENGEMBANGAN KAWASAN PARIWISATA DANAU TOBA, KABUPATEN TOBA SAMOSIR
}

\author{
Toba Lake Tourism Area Development in Toba Samosir Regency
}

Rizky Arimazona Siregar ${ }^{1}$, Hanny Wahidin Wiranegara $^{1}$, Henky Hermantoro ${ }^{2}$

Diterima: 28 November 2017

Disetujui: 1 Maret 2018

\begin{abstract}
Abstrak: Kawasan pariwisata Danau Toba termasuk Kawasan Strategis Pariwisata Nasional (KSPN), tetapi pada lima tahun terakhir jumlah kunjungan wisatawan masih rendah. Penelitian ini bertujuan mengidentifikasi aspek dalam pengembangan kawasan pariwisata yang kondisinya bermasalah dan usulan perbaikannya. Penelitian ini bersifat kuantitatif, digunakan desain survey angket. Kondisi aspek-aspek pengembangan kawasan pariwisata yang dianalisis meliputi: daya tarik wisata, aksesibilitas, prasarana dan sarana, kondisi sosial dan dukungan masyarakat. Semua aspek dijabarkan ke dalam indikator yang menjadi dasar disusunnya pernyataan dalam angket dengan menggunakan skala Likert. Berdasarkan uji chi square, semua aspek pengembangan kawasan pariwisata Danau Toba memiliki kategori yang berbeda secara signifikan. Hasil menunjukkan, bahwa aspek aksesibilitas dan dukungan masyarakat memiliki kategori lebih rendah dibanding aspek lainnya. Aspek yang perlu diprioritaskan dalam pengembangan kawasan pariwisata Danau Toba di Kabupaten Toba Samosir adalah aspek aksesibilitas. Terkait dengan aspek ini diperlukan upaya penyediaan dan perbaikan kondisi aksesibilitas untuk pengembangan kawasan pariwisata Danau Toba di Kabupaten Toba Samosir.
\end{abstract}

Kata kunci: kawasan pariwisata, aspek pengembangan, Danau Toba

\begin{abstract}
The Toba Lake tourism area is one of The National Tourism Strategic Areas (KSPN). In the last five years, the number of visitors is still low. The aim of this study is to identify the problematic aspects in developing tourism area and the efforts to overcome it. This research is quantitative and used design survey. The aspects in developing the tourism area analyzed were: tourist attraction, accessibility, infrastructure, and facilities, as well as social condition and community support. All those aspects were elaborated into indicators which set to be the statements in questionnaire using the Likert scale. Based on chi-square test, all the aspects has different category significantly. The results showed that accessibility and community support were the aspects which the lower category than others. But, the accessibility needs to be prioritized in developing the Toba Lake tourism area in Toba Samosir regency. It is required efforts to provide and improve its accessibility in developing this Toba Lake tourism area in Toba Samosir regency.
\end{abstract}

Keywords: tourism area, aspects of development, Toba Lake

\footnotetext{
${ }^{1}$ Program Studi Perencanaan Wilayah dan Kota, FALTL, Universitas Trisakti.

${ }^{2}$ Program Studi Pariwisata, FPAR, Universitas Pancasila
}

Korespondensi: rzarimazona@gmail.com 


\section{PENDAHULUAN}

Dalam pengembangan kawasan pariwisata, Danau Toba merupakan salah satu dari 88 yang termasuk ke dalam Kawasan Strategis Pariwisata Nasional (KSPN) berdasarkan Peraturan Pemerintah Nomor 50 Tahun 2011 tentang Rencana Induk Pembangunan Kepariwisataan Nasional Tahun 2010-2025, sehingga menjadi prioritas dalam pembangunan kepariwisataan. Berdasarkan Undang-Undang Nomor 10 Tahun 2009, Kawasan Strategis Pariwisata adalah kawasan yang memiliki fungsi utama pariwisata atau memiliki potensi untuk pengembangan pariwisata yang mempunyai pengaruh penting dalam satu atau lebih aspek, seperti pertumbuhan ekonomi, sosial dan budaya, pemberdayaan sumber daya alam, daya dukung lingkungan hidup, atau pertahanan dan keamanan. Terkait pengembangan kawasan pariwisata Danau Toba sebagai kawasan pariwisata prioritas khususnya pada bagian wilayah Kabupaten Toba Samosir terdapat peraturan pariwisata yang mendukung pengembangan kawasan ini, yaitu Peraturan Presiden Nomor 81 Tahun 2014 tentang Rencana Tata Ruang Kawasan Danau Toba dan Sekitarnya. Peraturan tersebut berisikan tentang aspek pembangunan dan pengembangan kawasan pariwisata Danau Toba.

Sebagai KSPN, kawasan pariwisata Danau Toba merupakan prioritas pembangunan destinasi wisata di Indonesia yang memiliki skala pelayanan nasional dan internasional. Dengan status tersebut, kawasan pariwisata Danau Toba seharusnya mampu memberikan kontribusi, dan kondisi aspek-aspek kepariwisataan seharusnya lebih memadai dibandingkan kawasan pariwisata lainnya yang tidak termasuk KSPN. Terkait dengan hal tersebut, maka perlu diidentifikasi aspek-aspek pengembangan kawasan pariwisata yang masih bermasalah guna merumuskan upaya agar jumlah kunjungan wisatawan di kawasan pariwisata Danau Toba dapat meningkat, khususnya pada wilayah Kabupaten Toba Samosir. Wilayah ini merupakan salah satu pintu masuk ke kawasan pariwisata Danau Toba dengan kunjungan wisatawan paling kecil dibandingkan dengan pintu masuk di dua kabupaten lainnya (Kabupaten Simalungun dan Kabupaten Samosir). (lihat Gambar 1).

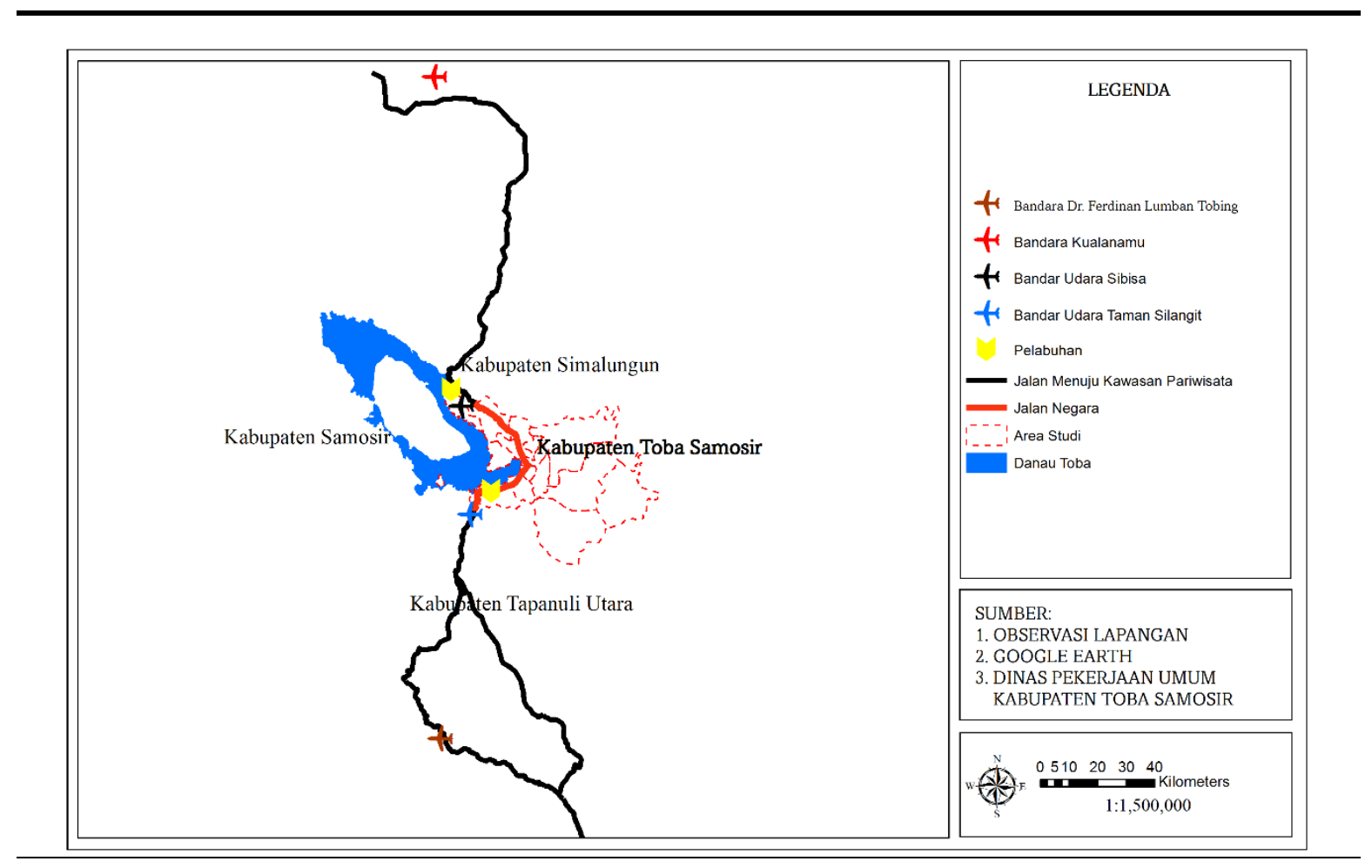

Gambar 1. Wilayah Studi: Kawasan Pariwisata Danau Toba di Kabupaten Toba Samosir 
Untuk keberhasilan pembangunan dan pengembangan kawasan pariwisata terdapat aspek-aspek yang perlu diperhatikan. Berdasarkan UU Nomor 10 Tahun 2009 tentang kepariwisataan disebutkan aspek-aspek dalam pengembangan dan pembangunan kawasan pariwisata yang meliputi daya tarik wisata, aksesibilitas, prasarana dan sarana, dan masyarakat.

Selain berdasarkan undang-undang terdapat aspek-aspek sebagai penunjang lainnya untuk mendukung pembangunan dan pengembangan kawasan pariwisata diantaranya menurut Yoeti (2002, dalam Rusnanda 2015) mengungkapkan tiga aspek penting dalam pembangunan dan pengembangan kawasan pariwisata, meliputi: atraksi (attraction), aksesibilitas (accesibility), fasilitas (amenities). Menurut Medlik (1980, dalam Gautama 2012) terdapat langkah-langkah pengembangan pariwisata meliputi 4A, yaitu: attractiveness, accessibility, amenities, ancillary. Demikian pula Nugroho (2009) mengemukakan aspek-aspek daya tarik wisata, aksesibilitas, prasarana dan sarana, serta masyarakat dalam pengembangan kawasan pariwisata. Dalam penelitian ini digunakan empat aspek tersebut: daya tarik wisata, aksesibilitas, prasarana dan sarana, serta dukungan masyarakat lokal.

Rincian atas ke empat aspek tersebut adalah sebagai berikut. Diungkapkan oleh Gunn (2002 dalam Alam 2010) bahwa aspek daya tarik wisata adalah sebagai daya pikat, dan perangsang. Daya tarik wisata terdiri atas semua hal yang berhubungan dengan lingkungan alami, kebudayaan, dan keunikan yang berguna untuk menarik wisatawan (Inskeep, 1991 dalam Rachman, 2011). Menurut Mc Intosh, daya tarik wisata terdiri atas sumber daya alam meliputi iklim, bentuk alam, flora, fauna, sungai, pantai, pemandangan alam, sumber mata air, sanitasi dan lainnya (1995, dalam Rachman 2011). Sementara menurut Burkart dan Medlik (2004, dalam Wardiyanto 2011) daya tarik wisata terdiri atas ketertarikan wisatawan yang dipengaruhi oleh keragaman maupun kualitas atraksi seperti taman, pusat hiburan, pusat belanja, pusat konvensi, kasino atau lainnya.

Aksesibilitas terdiri atas keseluruhan infrastruktur transportasi yang menghubungkan tempat tinggal wisatawan dengan objek dan daya tarik wisata yang dituju maupun yang menghubungkan objek wisata di daerah tujuan wisata (Burkart dan Medlik, 2004 dalam Wardiyanto 2011). Menurut Gun (2002, dalam Alam 2010), aksesibilitas adalah kemudahan mencapai lokasi, informasi berupa peta, buku petunjuk, artikel, brosur, internet. Aksesibilitas terdiri atas akses yang menghubungkan dari dan menuju termasuk jenis fasilitas dan pelayanan yang berhubungan dengan transportasi darat, laut, udara (Inskeep, 1991 dalam Rachman 2011). Sementara menurut Mc Intosh, aksesibilitas terdiri atas kapal laut, pesawat terbang, kereta api, bus, dan fasilitas transportasi lainnya (1995, dalam Rachman 2011).

Prasarana dan sarana terdiri atas jaringan air bersih, limbah, gas, listrik, telekomunikasi, drainase, jalan raya, rel kereta api, bandara (Mc Intosh, 1995 dan Inskeep, 1991 dalam Rachman 2011), termasuk fasilitas rumah makan dan hotel (Gunn, 2002 dalam Alam 2010) serta bank, penukaran uang, telekomunikasi, persewaan alat transportasi atau barang lainnya yang mendukung kegiatan wisata (Burkart dan Medlik, 2004 dalam Wardiyanto 2011).

Dukungan masyarakat terdiri atas sikap ramah tamah, dan sopan santun penduduk setempat (Mc Intosh, 1995 dalam Rachman 2011; Cooper et al, 2008; Inskeep, 1995; Swarbrooke, 1999 dalam Teguh, 2015) mengungkapkan masyarakat pariwisata seperti kesetaraan hubungan tamu-tuan rumah, penguatan karakteristik lokal, kepentingan masyarakat setempat, kualitas pelayanan, sarat muatan dari semua aspek, kekentalan relasi antara lingkungan fisik, dan sosial budaya.

\section{METODE}

Lokasi penelitian adalah kawasan pariwisata Danau Toba di dataran tinggi Bukit Barisan, pada bagian wilayah Kabupaten Toba Samosir, Provinsi Sumatera Utara. Kabupaten Toba Samosir merupakan pintu masuk wisatawan yang berkunjung ke kawasan pariwisata Danau Toba. Waktu penelitian dilaksanakan pada tanggal 16 Mei 2016 sampai tanggal 9 Juni 2016. 
Empat aspek pengembangan kawasan pariwisata yang dikaji (daya tarik wisata, aksesibilitas, prasarana dan sarana, sosial dan dukungan masyarakat) dalam penelitian ini dijabarkan ke dalam indikator dengan rincian sebagai berikut.

1. Daya tarik wisata: kemenarikan daya tarik (obyek wisata) dalam memberi kesan ingin berkunjung kembali, kemenarikan merchandise, harga tiket masuk, kebersihan daya tarik wisata, kenyamanan berada pada daya tarik wisata, kepuasan wisatawan terhadap fasilitas di daya tarik wisata.

2. Aksesibilitas: transportasi yang digunakan menuju Danau Toba, transportasi yang digunakan menuju daya tarik wisata, ketersediaan angkutan umum, ketersediaan petunjuk jalan, ketersediaan petunjuk daya tarik wisata berupa brosur, pamflet, dan peta, kondisi jalan yang dilalui, kualitas permukaan jalan yang dilalui, lama waktu perjalanan.

3. Prasarana dan sarana: kemudahan melakukan komunikasi, ketersediaan air bersih, kemudahan mendapatkan air bersih, ketersediaan tempat sampah, kemudahan mendapatkan tempat sampah, kebersihan, ketersediaan toilet umum, ketersediaan penginapan, ketersediaan tempat makan, kepuasan atas menu makanan dan minuman yang tersedia, kepuasan wisatawan atas pelayanan, ketersediaan tempat parkir, kemudahan jangkauan lokasi parkir, ketersediaan toko penjual cinderamata, harga barang cinderamata.

4. Dukungan sosial masyarakat dilihat dari dua sisi. Dari sisi wisatawan meliputi: kesediaan masyarakat menjadi pembimbing wisata, kesediaan masyarakat menyediakan jasa penginapan, kesediaan masyarakat menyediakan jasa penyewaan kendaraan, keberlangsungan budaya dalam keseharian masyarakat lokal, sikap ramah masyarakat lokal. Dukungan sosial masyarakat dari sisi masyarakat sendiri: kesiapan masyarakat dalam pengembangan pariwisata, kesediaan bekerjasama dengan pemerintah, kesediaan menjaga kebersihan kawasan Danau Toba, kesediaan menyediakan fasilitas penginapan, kesediaan masyarakat menyediakan usaha jasa penyewaan kendaraan, kesediaan masyarakat melakukan usaha kerajinan, kesediaan masyarakat menyediakan usaha makanan/minuman, kesediaan masyarakat menerima wisatawan, kesediaan masyarakat memberikan informasi kebudayaan Batak, kesediaan masyarakat melakukan aktivitas kebudayaan dalam keseharian, kesediaan masyarakat menjadi pembimbing wisatawan, kesediaan masyarakat memberikan harga yang terjangkau dari usaha barang dan jasa.

Survey angket meliputi ke empat aspek tersebut ditujukan kepada wisatawan dan terkait aspek dukungan sosial, angket ditujukan pula pada masyarakat setempat. Berdasarkan atas jumlah angket yang memenuhi kelengkapan jawaban, dipilih 100 buah angket jawaban untuk responden wisatawan dan 100 angket untuk responden masyarakat setempat, untuk dikompilasi dan dianalisis. Jumlah sampel memenuhi rumus Slovin. Angket untuk wisatawan disebarkan melalui 3 cara. Pertama, penyebaran dilakukan pada pintu masuk dan pengumpulan dilakukan di pintu ke luar. Cara kedua adalah dengan mendatangi wisatawan yang sedang melakukan kunjungan wisata saat wisatawan akan mengakhiri kunjungan wisatanya. Ketiga, disebar dengan bantuan pemandu wisata, satu angket untuk satu rombongan. Sementara angket untuk masyarakat lokal dibagikan dengan cara mendatangani rumah-rumah mereka maupun disebar pada tempat mereka berjualan di kawasan Danau Toba.

Dalam menentukan aspek bermasalah yang perlu diperbaiki pada kawasan pariwisata Danau Toba pada wilayah studi Kabupaten Toba Samosir menggunakan analisis statistik deskriptif yang meliputi distribusi frekuensi, analisis kategori rentang penilaian, tabulasi silang, dan analisis korelasi.

\section{HASIL DAN PEMBAHASAN}

Hasil analisis kategori atas aspek-aspek pengembangan kawasan pariwisata Danau Toba di Kabupaten Toba Samosir adalah sebagai berikut: 


\section{Daya Tarik Wisata}

Aspek daya tarik wisata menurut pendapat $70 \%$ responden termasuk kategori tinggi. Hanya dua indikator pada aspek ini yang memiliki kategori sedang, yaitu kebersihan daya tarik wisata (menurut $75 \%$ responden), kepuasan atas fasilitas pada daya tarik wisata (71\% responden). Kondisi ini dipengaruhi oleh masih minimnya pengelolaan kawasan pariwisata Danau Toba.

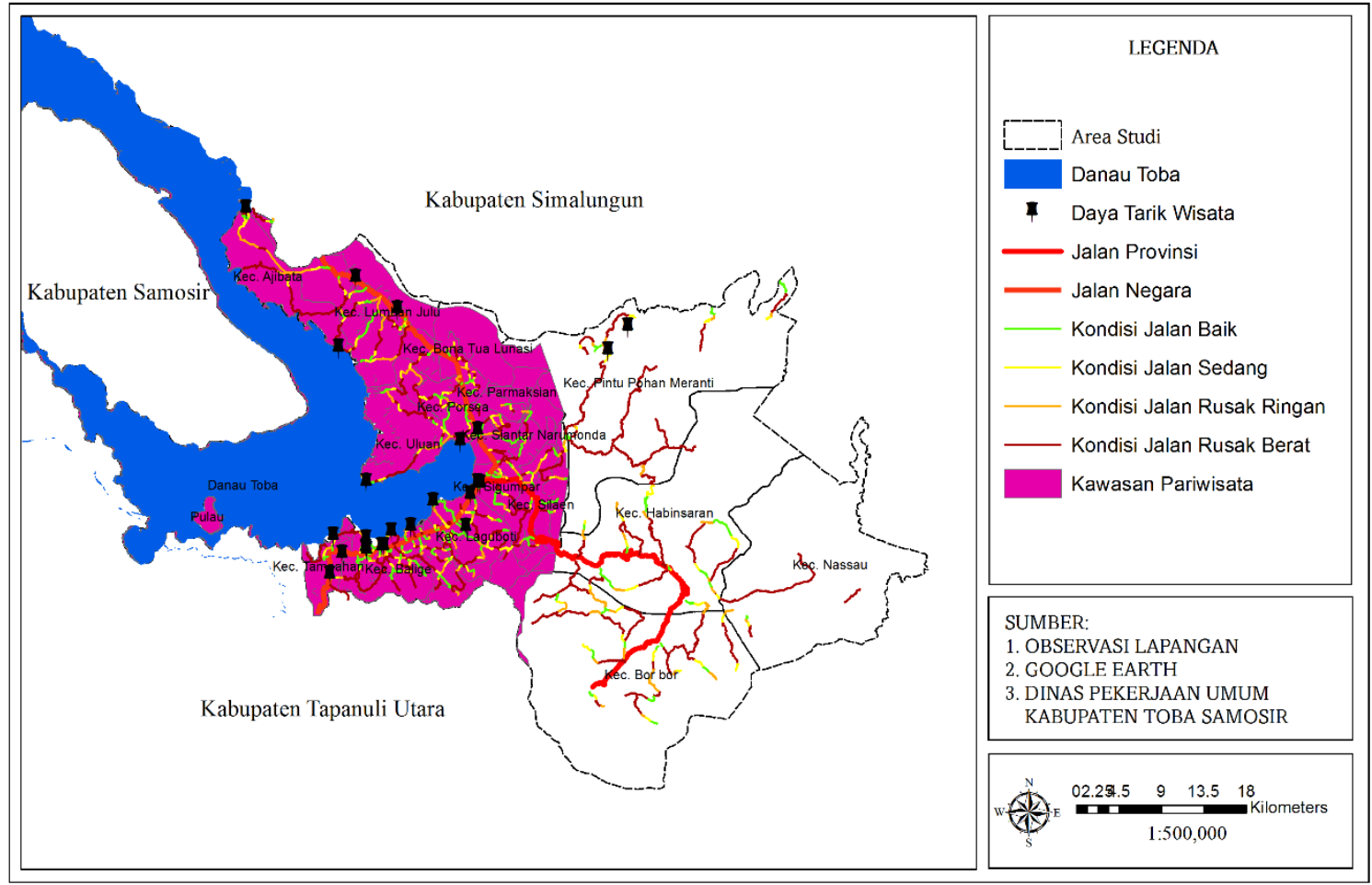

Gambar 2. Persebaran Daya Tarik Wisata Kawasan Pariwisata Kabupaten Toba Samosir

\section{Aksesibilitas}

Aspek aksesibilitas termasuk kategori sedang menurut 80\% responden. Wisatawan masih merasa kesulitan dan tidak nyaman saat menempuh perjalanan sampai menuju daya tarik wisata. Sebanyak 68\% responden berpendapat angkutan umum masih sulit. Ketersediaan petunjuk jalan di dalam kawasan pariwisata Danau Toba juga belum memadai menurut $66 \%$ responden. Kemudahan pencapaian daya tarik wisata dengan bantuan petunjuk daya tarik wisata berbasis online juga belum memadai (menurut $72 \%$ responden). Kondisi permukaan jalan di dalam kawasan pariwisata Danau Toba masih belum memadai, masih terdapat permukaan tanah untuk mencapai daya tarik wisata. Kondisi permukaan jalan ini memiliki kategori sedang (74\% responden) (lihat Gambar 2 dan Gambar 3).

\section{Prasarana dan Sarana}

Aspek prasarana dan sarana pada kawasan pariwisata Danau Toba ini termasuk kategori tinggi menurut 59\% responden. Walaupun masuk kategori tinggi, masih terdapat beberapa indikator pada aspek ini yang memiliki kategori sedang, yaitu: kemudahan mendapatkan tempat 
sampah (menurut 69\% responden), kepuasan atas pelayanan tempat makan (menurut 57\% responden), kepuasan atas menu makanan yang tersedia (62\%), kemudahan mendapatkan tempat parkir (49\%), kemudahan membeli cinderamata khas daerah $(67 \%)$, keterjangkauan harga cinderamata $(64 \%)$.

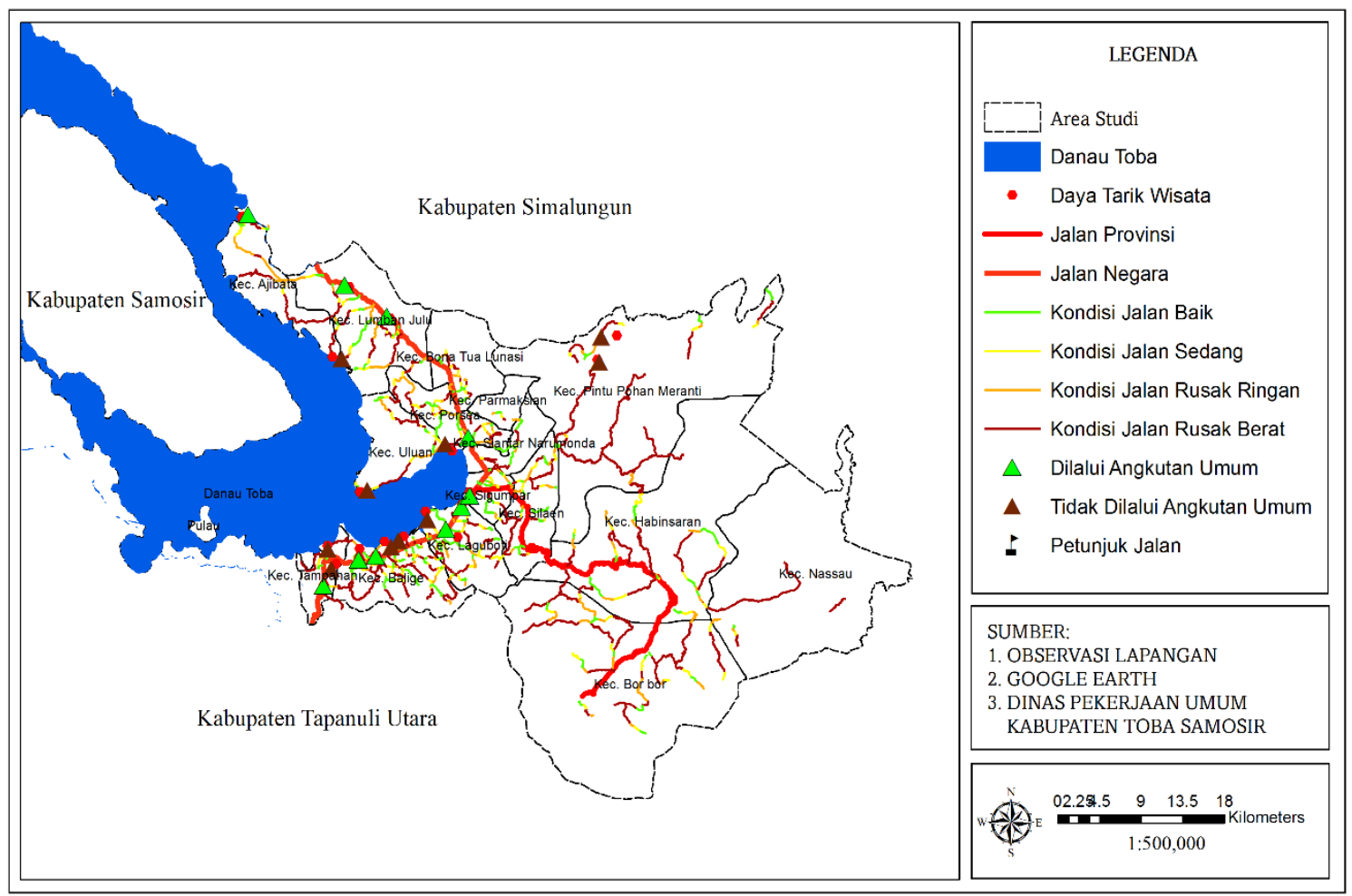

\section{Gambar 3. Kondisi Aksesibilitas Kabupaten Toba Samosir}

\section{Dukungan Sosial Masyarakat}

Terkait dukungan sosial masyarakat, jawaban angket berasal dari dua sumber, wisatawan dan masyarakat setempat. Dari sisi wisatawan, dukungan sosial masyarakat termasuk dalam kategori sedang menurut $66 \%$ responden wisatawan. Pada indikator-indikator berikut masuk kategori sedang: kurangnya partisipasi masyarakat dalam menawarkan jasa pembimbing wisata (menurut $71 \%$ responden); dalam menawarkan jasa tempat penginapan (menurut $71 \%$ responden), dalam menawarkan sewa kendaraan (menurut 68\% responden), dan sikap masyarakat terhadap wisatawan yang datang (55\%).

Dari sisi masyarakat setempat termasuk dalam kategori sedang menurut $97 \%$ responden. Mereka siap berpartisipasi dalam pengembangan kawasan pariwisata Danau Toba. Masyarakat setempat berpendapat masih belum memadainya kerjasama dengan pemerintah daerah dalam pengembangan kawasan pariwisata Danau Toba (menurut 83\% responden).

\section{Aspek yang bermasalah dan perlu prioritas penanganan}

Aspek yang bermasalah dan perlu diprioritaskan untuk ditangani ditentukan berdasarkan nilai kategori yang lebih rendah tetapi memiliki kekuatan korelasi tinggi dengan aspek lainnya. Berdasarkan hasil analisis kategori, aspek aksesibilitas dan dukungan sosial masyarakat memiliki nilai lebih rendah dibandingkan dengan aspek lainnya. Untuk menentukan aspek yang prioritas 
di antara ke dua aspek tersebut dilakukan perbandingan mana yang memiliki korelasi lebih baik terhadap aspek-aspek lainnya agar jika diintervensi memiliki pengaruh lebih besar terhadap perubahan aspek-aspek lainnya.

Hasil analisis korelasi antar aspek diperoleh gambaran sebagai berikut:

a. Korelasi aksesibilitas dengan dukungan sosial masyarakat: hasil uji chi square menunjukkan hasil yang signifikan dengan taraf signifikansi 0,000. Korelasinya sebesar 0,603 artinya memiliki korelasi yang kuat.

b. Korelasi aksesibilitas dengan daya tarik wisata: hasil uji chi square menunjukkan hasil yang signifikan dengan taraf signifikansinya 0,001. Korelasi antara aksesibilitas dengan daya tarik wisata sebesar 0,47 artinya memiliki korelasi yang cukup.

c. Korelasi aksesibilitas dengan prasarana dan sarana: hasil uji chi square menunjukkan hasil yang signifikan dengan taraf signifikansi 0,001. Korelasinya sebesar 0,586 artinya memiliki korelasi kuat.

d. Korelasi dukungan sosial masyarakat dengan prasarana dan sarana: hasil uji chi square menunjukkan hasil yang signifikan dengan taraf signifikansi 0,000. Korelasinya sebesar 0,636 artinya memiliki korelasi yang kuat.

e. Korelasi prasarana dan sarana dengan daya tarik wisata: hasil uji chi square menunjukkan hasil yang signifikan dengan taraf signifikansi 0,000. Korelasinya sebesar 0,399 artinya memiliki korelasi yang cukup.

Gambaran korelasi antar aspek secara lengkap diperlihatkan pada Gambar 4.

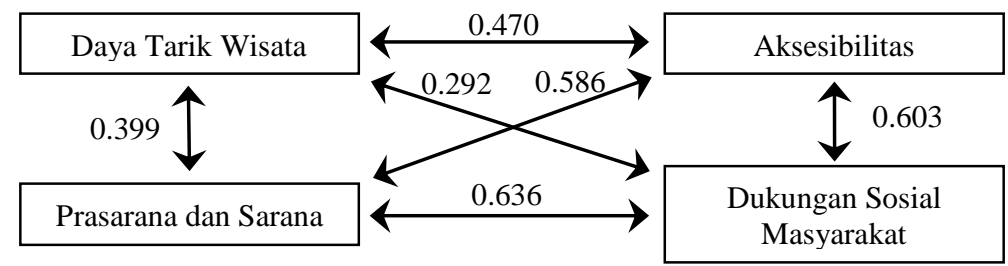

Sumber: Hasil Analisis, 2016

\section{Gambar 4. Korelasi Antar Aspek Pengembangan Kawasan Pariwisata Danau Toba}

Berdasarkan keterangan besarnya korelasi antaraspek pada Gambar 4, maka tampak aspek aksesibilitas merupakan aspek prioritas yang perlu diintervensi karena selain bermasalah juga memiliki hubungan yang kuat dengan aspek lainnya. Artinya, dengan memilih aspek ini sebagai prioritas untuk ditingkatkan kondisinya maka diharapkan akan mempengaruhi peningkatan kondisi aspek lainnya.

\section{Upaya peningkatan kondisi aspek aksesibilitas}

Aspek aksesibilitas merupakan hal penting untuk ditingkatkan kondisinya. Peningkatan kondisi aksesibilitas akan lebih memudahkan wisatawan menuju kawasan pariwisata Danau Toba maupun untuk pergerakan di dalam kawasan. Mayoritas wisatawan memiliki waktu tempuh perjalanan yang relatif lama, yaitu antara 5-8 jam perjalanan. Lama waktu perjalanan ini terkait dengan kondisi permukaan jalan, angkutan umum, dan ketersediaan petunjuk jalan. Makin lama perjalanan, wisatawan makin merasakan kejenuhan dan mengalami kelelahan. Oleh karena itu, perlu peningkatan kondisi aspek aksesibilitas. (lihat Gambar 5, Gambar 6 dan Gambar 7 memperlihatkan kondisi aspek aksesibilitas).

Berbagai moda pilihan yang dapat digunakan wisatawan yang berasal dari luar Kabupaten Toba Samosir adalah: moda transportasi udara (Bandara Silangit, Bandara Sibisa, Bandara 
Kualanamu, Bandara Dr. Ferdinan Lumban Tobing), moda transportasi darat (dari utara dapat dilalui dari provinsi Aceh, kota Medan, dari selatan dapat dilalui dari Kabupaten Tapanuli Selatan, Sibolga dan Provinsi Sumatera Barat); moda transportasi danau (penyeberangan dari Kabupaten Samosir). Berdasarkan titik datang wisatawan yang perlu diperhatikan adalah kondisi prasarana dan sarana transportasinya. Wisatawan pengguna moda transportasi udara, dari Bandara Kualanamu ke kawasan pariwisata membutuhkan waktu \pm 8 jam perjalanan, sehingga perlu adanya dukungan bandara kecil untuk mengurangi waktu tempuh. Upaya jangka panjang dalam peningkatan pelayanan moda trasportasi udara untuk pengembangan kawasan pariwisata Danau Toba adalah percepatan pembangunan Bandara Sibisa agar wisatawan dapat dengan mudah mencapai Kabupaten Toba Samosir. Selanjutnya, upaya jangka pendek adalah perlu adanya tambahan penerbangan pada Bandara Taman Silangit sebagai alternatif agar wisatawan dapat mengunjungi kawasan pariwisata Danau Toba ini dengan biaya penerbangan yang tidak terlalu mahal.
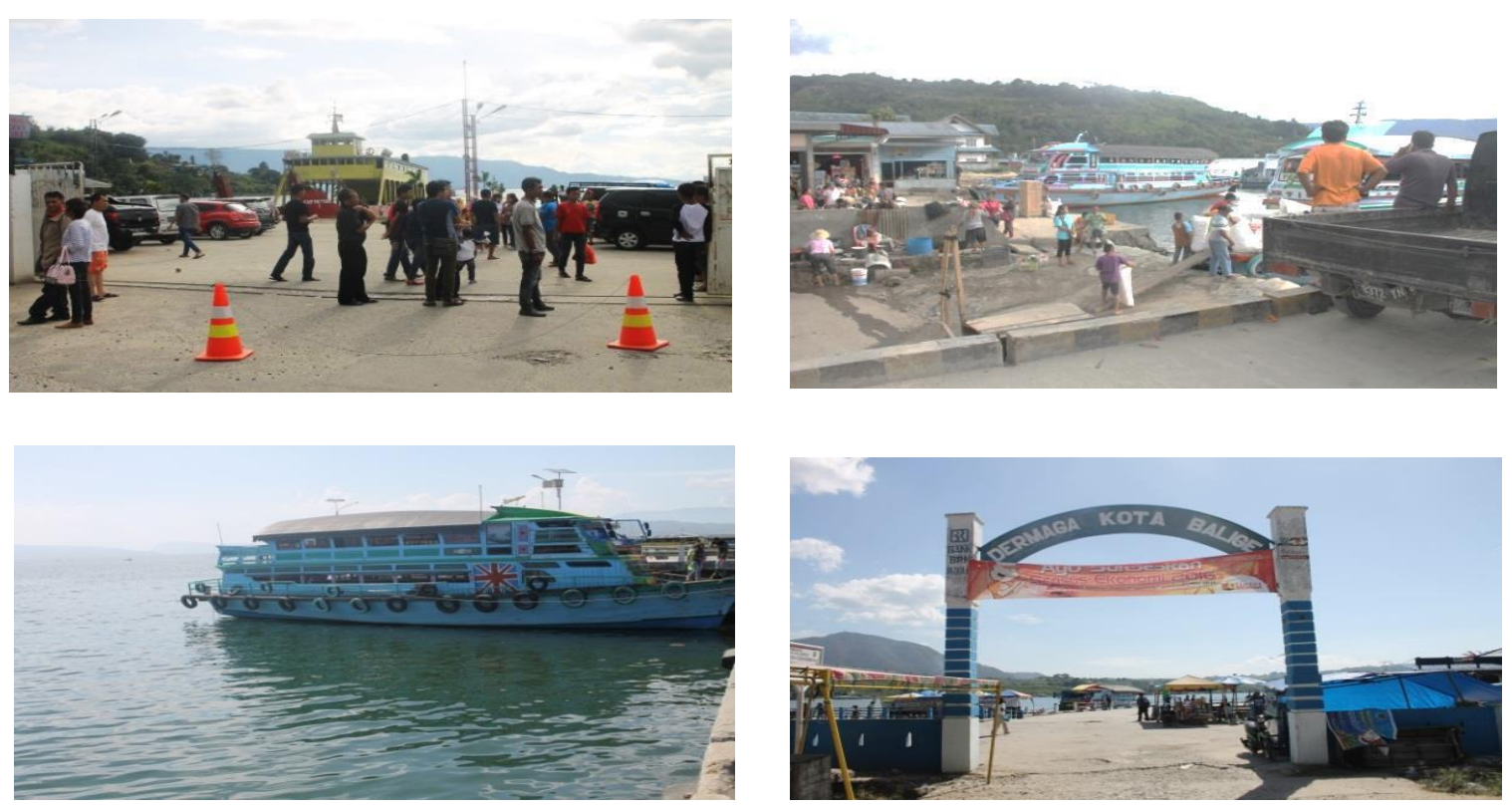

Sumber: Observasi 2016

\section{Gambar 5. Moda Transportasi Danau}

Terkait moda transportasi danau, upaya yang perlu ditingkatkan dalam pengembangan kawasan pariwisata Danau Toba adalah perlu adanya kapal penyeberangan yang aman dan nyaman. Danau Toba sebagai daya tarik utama berkaitan dengan upaya peningkatan moda transportasi danau adalah pembenahan kapal penyeberangan dengan penyediaan tempat duduk agar penumpang dapat menikmati pemandangan lingkungan Danau Toba, tersedianya loket pembayaran dengan penetapan tarif penyeberangan yang jelas untuk menekan adanya permainan tarif penyeberangan agar wisatawan dapat merasa nyaman. Ketersediaan kapal penyeberangan perlu ditingkatkan. Hal ini terutama pada waktu puncak seperti waktu libur sekolah, agar wisatawan tidak menunggu lama untuk dapat menyeberang ke Pulau Samosir maupun sebaliknya. Di samping itu perlu peningkatan keamanan dalam penyeberangan tersebut dengan menyediakan fasilitas yang memadai seperti tempat penyimpanan pelampung, alat pemadam kebakaran, dan tersedianya petugas keamanan dalam kapal penyeberangan. 
Ketersediaan fasilitas keamanan tersebut dapat meningkatkan rasa aman wisatawan yang hendak mengunjungi kawasan pariwisata Danau Toba.

Upaya peningkatan kondisi aspek aksesibilitas terkait moda transportasi darat, hal yang perlu diperhatikan adalah ketersediaan dan kualitas pelayanan angkutan umum. Saat ini kondisi angkutan umum untuk menunjang wisatawan masih kurang baik. Dari segi kenyamanannya, angkutan umum perlu ditingkatkan seperti cara mengoperasikan kendaraan yang nyaman.

Kondisi jalan dari arah selatan, yaitu dari Kabupaten Tapanuli Utara, Selatan, Sibolga dan Provinsi Sumatera Barat menuju kawasan pariwisata berdasarkan hasil survey lapangan adalah kurang baik. Perlu ditingkatkan kualitas jalannya, selain untuk kenyamanan, dan keamanan juga untuk mengurangi waktu tempuh perjalanan. Wisatawan pengguna transportasi darat dari arah utara, yaitu dari Kota Pematang Siantar, Kota Medan, Kabupaten Simalungun, dan Provinsi Aceh umumnya kondisi cukup baik, hanya bagian kecil yang berkondisi kurang baik (lihat Gambar 6 dan Gambar 7).

Dalam upaya pengembangan kawasan pariwisata Danau Toba pada aspek aksesibilitas di dalam kawasan pada bagian wilayah Kabupaten Toba Samosir perlu ditingkatkan kondisi dan kualitas permukaan jalannya. Menurut wisatawan kondisi dan permukaan jalan yang tersedia mayoritas dalam kondisi rusak, sehingga tingkat kenyamanan wisatawan terganggu. Kualitas jalan di dalam kawasan perlu perbaikan agar wisatawan dapat mengakses tujuan wisatanya dengan nyaman. Selain mayoritas kualitas jalan yang tidak baik, lebar jalan juga perlu peningkatan. Mayoritas lebar jalan relatif sempit sehingga menyulitkan wisatawan yang menggunakan kendaraan pribadi, dan pengguna bus travel.
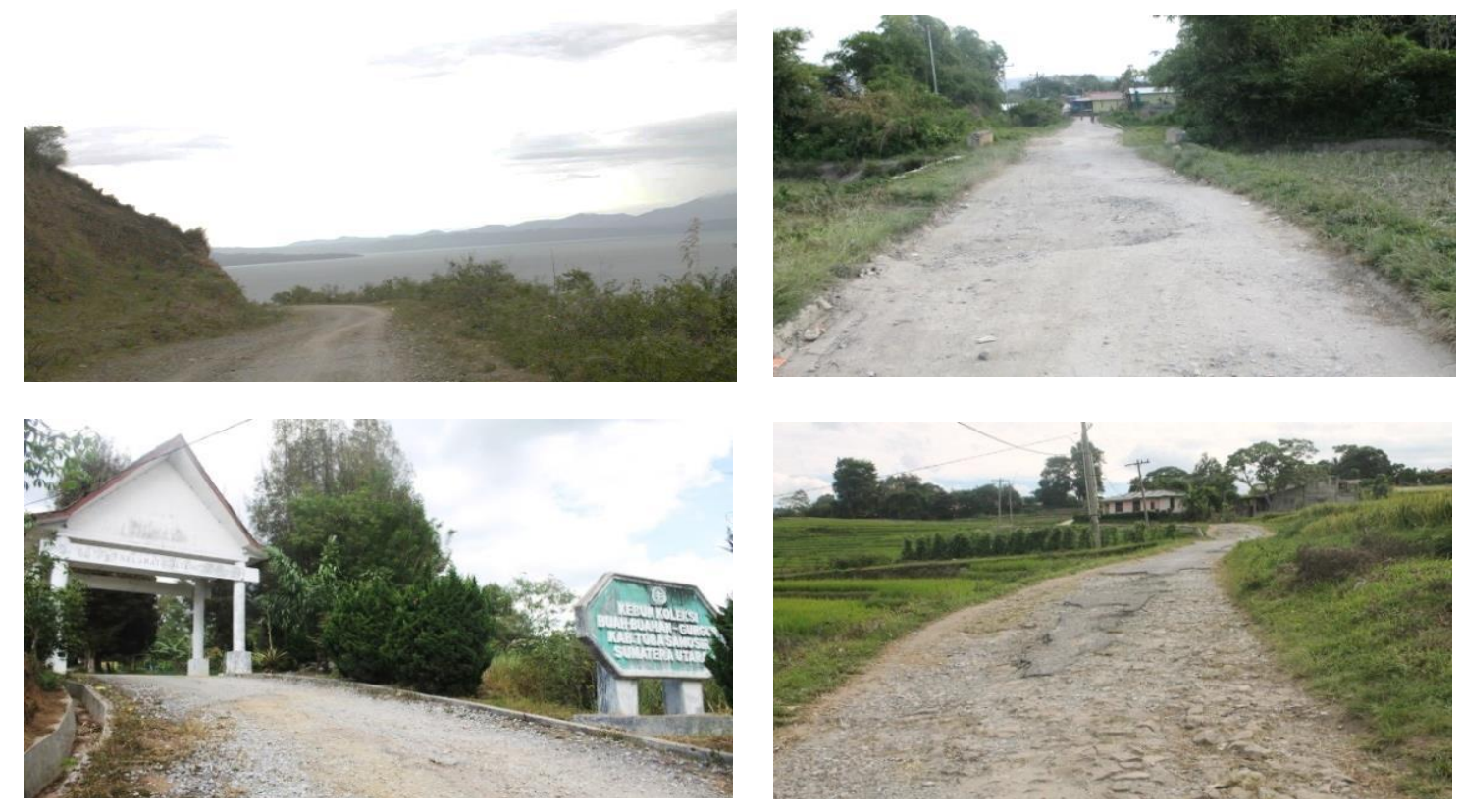

Sumber: Observasi 2016

\section{Gambar 6. Kondisi jaringan jalan di dalam Kawasan Pariwisata Danau Toba}

Untuk wisatawan berpenghasilan rendah perlu penyediaan angkutan umum. Masih minimnya ketersediaan angkutan umum berakibat pada masih banyaknya daya tarik wisata yang tidak dilalui angkutan umum. Daya tarik wisata yang dilalui oleh jalan negara sudah terdapat angkutan umum, tetapi pada jalan kabupaten dan jalan desa ketersediaan angkutan umum masih belum memadai. 
Petunjuk jalan di luar dan di dalam kawasan pariwisata masih kurang memadai. Petunjuk jalan sebagian besar tersedia di luar kawasan terutama pada jalan negara. Sementara pada jalan kabupaten dan jalan desa masih belum memadai, padahal petunjuk jalan sangat dibutuhkan bagi wisatawan pengguna kendaraan pribadi. Penyediaan petunjuk jalan harus ditingkatkan agar tidak menyulitkan wisatawan mencapai lokasi daya tarik wisata terutama yang berasal dari luar Kabupaten Toba Samosir.

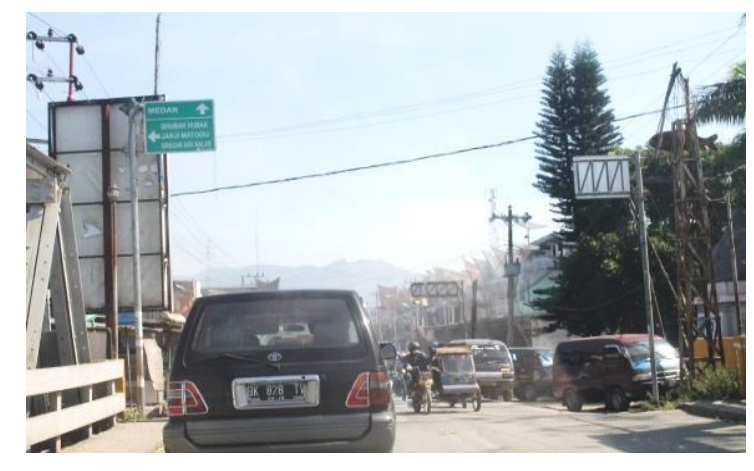

B

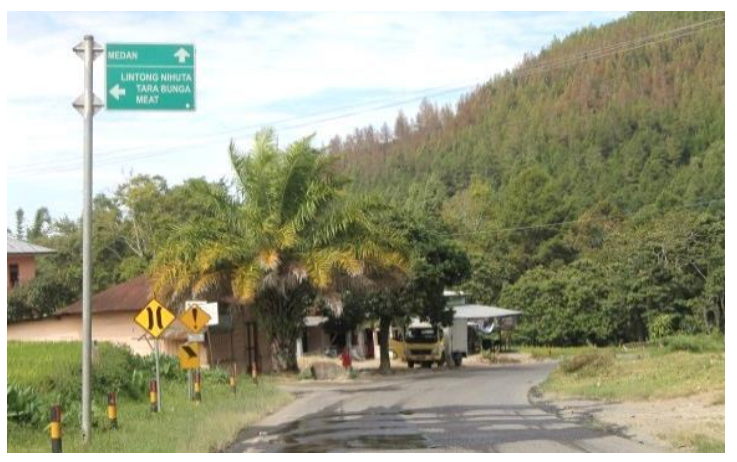

C

Sumber: Hasil Observasi, 2016
Keterangan:

A: Di Kecamatan Porsea

B: Di Kecamatan Balige

C: Di Kecamatan Tampahan

\section{Gambar 7. Petunjuk jalan ke Kawasan Pariwisata Danau Toba}

\section{Upaya peningkatan kondisi aspek lainnya}

Selain peningkatan pada aspek aksesibilitas, perlu upaya peningkatan kondisi aspek lainnya dalam pengembangan kawasan pariwisata Danau Toba di Kabupaten Toba Samosir. Permasalahan dalam aspek prasarana dan sarana di antaranya adalah: 1) ketersediaan toilet di lokasi daya tarik wisata sangat kurang memadai; 2) ketersediaan tempat parkir masih terbatas; 3) kurangnya tempat sampah; 4) tidak adanya toko cinderamata sehingga sukar mendapatkan cinderamata yang menjadi ciri khas. Akibat wisatawan sulit mendapatkan tempat sampah, maka pada lokasi daya tarik wisata dijumpai tumpukan sampah. Terkait hal ini perlu adanya sistem pengelolaan persampahan yang baik. Ketesediaan toilet umum pada lokasi daya tarik wisata masih sangat jauh dari kata layak. Banyak sekali toilet umum dalam kondisi rusak tidak terawat, kotor, dan bau. Perlu adanya pengelolaan toilet umum agar kondisinya terawat dengan baik sehingga pantas mendukung perannya sebagai kawasan pariwisata nasional yang strategis. Selain itu perlu diperhatikan juga di dalam pembangunan infrastruktur agar memberi dukungan 
kemudahan dan konektivitas menuju kawasan Danau Toba di Kabupaten Toba Samosir di satu sisi dan di sisi lain tidak berdampak pada kerusakan keindahan alam. Secara langsung maupun tidak langsung lingkungan pariwisata Danau Toba sesungguhnya menjual keindahan alamnya. Menurut Evita (2012) terdapat dampak positif dan dampak negatif dalam pembangunan infrastruktur. Dampak positifnya adalah meningkatnya pendapatan asli daerah (PAD) dan membuka lapangan pekerjaan. Sementara dampak negatifnya adalah berubahnya kondisi alamiah, munculnya pencemaran lingkungan, dan berubahnya fungsi ekologis seperti tata air akibat adalah konstruksi bangunan infrastruktur. Terkait dengan dampak negatif ini, dalam pengembangan kawasan pariwisata Danau Toba di Kabupaten Toba Samosir perlu kajian agar tidak terjadi kerusakan lingkungan Danau Toba. Menurut Sianturi (2004) Danau Toba mengalami degradasi dari berbagai aspek yang mengganggu keseimbangan lingkungan (ekosistem), sehingga perlu dikaji ulang dalam penataan perairan Danau Toba untuk tujuan pengembangan pariwisata. Menurut Kuswara (2007) pengelolaan kawasan sepanjang DTA akan menentukan tingkat kelestarian danau baik dilihat dari kualitas air maupun kuantitas air danau tersebut.

Ketersediaan tempat parkir pada kawasan pariwisata Danau Toba masih belum memadai, seperti kualitas permukaan tempat parkir dan pengaturan ruang parkir. Akibat hal ini, wisatawan kurang merasa aman dan nyaman untuk memarkir kendaraan ketika mengunjungi daya tarik wisata. Tercampurnya jenis kendaraan antara motor, mobil, bis, dan lain-lain di tempat parkir membuat tidak nyaman wisatawan karena ketika akan meninggalkan daya tarik wisata terhalang oleh kendaraan lain. Oleh karena itu, diperlukan pengelolaan parkir yang memadai.

Belum tersedia toko penjual kerajinan tangan/cinderamata sehingga wisatawan merasa kesulitan untuk mendapatkan hasil kerajinan khas daerah Toba Samosir. Wisatawan yang ingin membeli kerajinan tangan khas Toba Samosir harus menempuh perjalanan menuju Balige, Porsea, Laguboti, dan Ajibata. Oleh karena itu, perlu penyediaan toko penjual cinderamata/keranjinan tangan pada lokasi daya tarik wisata.

Permasalahan terkait daya tarik wisata adalah: gangguan akibat bangunan di pinggir danau, buangan limbah rumah tangga ke danau, pencemaran sampah, gangguan eceng gondok, fasilitas belum memadai, dan lain-lain. Masyarakat setempat khususnya di Kecamatan Balige memiliki bangunan tempat tinggal mayoritas berlokasi melewati garis sempadan Danau Toba. Berdasarkan peraturan, garis sempadan danau berada 50 meter dari titik air tertinggi yang pernah terjadi. Selain itu, masyarakat setempat juga membuang limbah rumah tangga ke Danau Toba sehingga mencemari air danau. Lokasi bangunan masyarakat di Kecamatan Balige dekat dengan daya tarik wisata Lumban Silintong, sehingga daya tarik tersebut terkena dampak pencemaran. Banyak sekali daya tarik wisata yang tersedia tercemari sampah. Terkait hal ini perlu penataan, pengelolaan, dan sosialisasi terhadap masyarakat setempat terkait lewat batas garis sempadan dan pentingnya mencegah pencemaran Danau Toba akibat sampah dan limbah dari rumah tangga.

Danau Toba juga tertutup eceng gondok. Banyaknya eceng gondok membuat gangguan estetika dan kebersihan. Penyebab timbulnya eceng gondok adalah pencemaran air limbah rumah tangga, limbah komersil, dan industri yang tidak ditangani dengan baik. Terkait hal ini perlu peraturan bagi sektor komersil dan industri agar dapat mengelola limbahnya sebelum dibuang ke perairan umum, untuk mengurangi pencemaran air Danau Toba.

Keberadaan kerambah mencemari kebersihan daya tarik wisata. Selain merugikan kesehatan masyarakat, keberadaan kerambah menyebabkan air danau keruh. Muncul kejadian gatal-gatal pada wisatawan yang melakukan aktifitas rekreasi pada daya tarik wisata yang terdapat kerambah tersebut. Perlu ditata lokasi kerambah agar tidak mencemari.

Fasilitas sosial dan fasilitas umum yang terdapat pada daya tarik wisata masih belum memadai. Sebagai contoh wisatawan yang beragama Islam merasakan kesulitan untuk mendapatkan mushola pada daya tarik wisata yang tersedia. Selain itu belum ada fasilitas 
pendukung rekreasi seperti banana boat, speed boat, dan lain-lain untuk menambah daya tarik wisata.

Aspek dukungan sosial masyarakat setempat dalam pengembangan kawasan pariwisata Danau Toba merupakan aspek penting dalam memberikan rasa aman dan nyaman bagi wisatawan yang berkunjung. Dukungan sosial masyarakat setempat di antaranya adalah kesediaan masyarakat menjadi pembimbing wisata, kesediaannya memberikan jasa penyewaan kendaraan, kesediaan masyarakat memberikan jasa penginapan, dan sikap dari masyarakat setempat terhadap wisatawan.

Kesediaan masyarakat menjadi pembimbing wisata (tourguide) adalah cukup penting karena mereka mengetahui sejarah, budaya, dan lain-lain yang dapat membantu wisatawan memahami daya tarik wisata yang ada di kawasan Danau Toba. Masyarakat setempat masih belum menyadari potensi ini yang dapat memberikan nilai ekonomi baginya. Pada kawasan pariwisata Danau Toba hanya di TB. Silalahi Center yang menyediakan pembimbing wisata. Oleh karena itu, perlu dilakukan sosialisasi dan pelatihan kepada masyarakat lokal agar mereka dapat berpartisipasi menjadi pembimbing wisata di kawasan pariwisata Danau Toba.

Kesediaan masyarakat untuk menyediakan jasa penginapan masih belum memadai. Pada beberapa titik terdapat desa binaan wisata homestay, yaitu pada daya tarik wisata Lumban BulBul Nauli, dan Meat. Sebagai desa binaan seharusnya menjadi contoh bagi masyarakat lainnya agar dapat berpartisipasi dalam pengembangan kawasan pariwisata. Perlu sosialisasi pada masyarakat setempat agar dapat memberikan ruang inap bagi wisatawan di rumahnya.

Partisipasi masyarakat memberikan jasa penyewaan kendaraan seperti di Tuktuk dapat memberikan penghasilan tambahan bagi masyarakat setempat. Oleh karena itu, masyarakat setempat perlu diberikan sosialisasi, pelatihan dan diberi kesempatan melalui program pemberdayaan masyarakat setempat untuk melakukan usaha jasa penyewaan kendaraan.

Diperlukan sikap ramah masyarakat setempat terhadap wisatawan. Karakter masyarakat yang keras, tegas, dan lantang terkadang tidak dapat diterima oleh wisatawan yang berasal dari luar daerah. Sikap terhadap wisatawan yang kurang ramah menjadi salah satu faktor pertimbangan wisatawan untuk berkunjung kembali ke kawasan pariwisata Danau Toba. Masyarakat Toba Samosir perlu diberi sosialisasi mengenai partisipasi dengan menerima dan membantu wisatawan yang melakukan kunjungan wisata.

Dengan permasalahan kondisi masyarakat tersebut perlu adanya peningkatan sumber daya manusia di kabupaten Toba Samosir. Menurut Nandi (2016, dalam Anugrah), pendidikan kepariwisataan merupakan salah satu kunci dalam mengembangkan potensi kepariwisataan (kawasan wisata), karena bidang ini memerlukan tenaga kerja terampil yang secara terus menerus harus dikembangkan. Dalam hal ini perlu adanya pendampingan pendidikan kepariwisataan untuk masyarakat Danau Toba khususnya pada kabupaten Toba Samosir. Selain itu perlu adanya kerjasama antara pemerintah, swasta, dan masyarakat yang merupakan tiga pilar utama di dalam pariwisata (Pitana dan Gayatri, 2005 dalam Sudana 2013). Dalam kerjasama antara tiga pilar tersebut, masyarakatlah yang berkenaan langsung dengan wisatawan dan menjadi roda dalam menjalani kebudayaan Batak di Kabupaten Toba Samosir. Swasta sebagai pemilik modal usaha di bidang pariwisata, dan pemerintah berfungsi pembinaan dan pengawasan berkaitan dengan pengembangan dan pengelolaan kawasan pariwisata Danau Toba di Kabupaten Toba Samosir ini.

\section{KESIMPULAN}

Di antara empat aspek dalam pengembangan kawasan pariwisata Danau Toba di Kabupaten Toba Samosir, aspek aksesibilitas dan aspek dukungan sosial masyarakat adalah yang terendah. Hasil penelitian menunjukkan: aspek daya tarik wisata (kategori tinggi menurut $70 \%$ responden), aspek aksesibilitas (kategori sedang menurut $80 \%$ responden), aspek prasarana dan sarana (kategori tinggi menurut 59\% responden), dan aspek dukungan sosial masyarakat 
(kategori sedang menurut 66\% responden). Dari ke empat aspek tersebut terdapat korelasi satu sama lain. Aspek aksesibilitas memiliki korelasi yang lebih tinggi ke berbagai aspek lainnya dibanding aspek dukungan sosial masyarakat, sehingga penanganan aspek aksesibilitas perlu diprioritaskan karena memiliki pengaruh searah/positif ke perbaikan aspek lainnya. Pemilihan prioritas diperlukan mengingat keterbatasan anggaran pemerintah daerah maupun pusat. Dalam aspek aksesibilitas perlu adanya kemudahan bagi wisatawan yang datang dengan perbaikan konektivitas dan keterkaitan antarmoda transportasi (darat, laut, udara) untuk menekan waktu tempuh, perlu adanya percepatan perbaikan kualitas jalan dan peningkatan kualitas permukaan jalan yang terdapat di Kabupaten Toba Samosir.

Dalam penanganan kondisi aspek daya tarik wisata diperlukan upaya sosialisasi, penataan, pengelolaan dan pengawasan yang melibatkan tiga pilar. Pilar masyarakat maupun swasta yang perlu dilibatkan terutama mereka yang menduduki garis sempadan danau, yang mendirikan usaha kerambah, yang terlibat dalam industri cinderamata, yang bertempat tinggal di seputar obyek daya tarik wisata, dll. Selain itu perlu dalam aspek prasarana dan sarana, perlu perbaikan fasilitas pendukung pariwisata seperti tempat sampah, toilet, restoran, tempat parkir, toko cinderamata., tempat penginapan.

\section{DAFTAR PUSTAKA}

Alam, W I. 2010. Identifikasi Presepsi dan Preferensi Pengunjung tentang Objek dan Daya Tarik Wisata Situ Bagendit Kabupaten Garut. Bandung: Teknik Perencanaan Wilayah dan Kota, Universitas Komputer Indonesia.

Anugrah, K. 2017. Pembangunan Pariwisata Daerah melalui Pengembangan Sumber Daya Manusia di Gorontalo. Jurnal Master Pariwisata Vol. 4 No. 1 Hal. 33-46.

Evita, R. 2012. Dampak Perkembangan Pembangunan Sarana Akomodasi Wisata terhadap Pariwisata Berkelanjutan di Bali. Jurnal Ilmiah Pariwisata.

Gautama I. G. O (2012). Evaluasi Perkembangan Wisata Bahari di Pantai Sanur. Jurnal Ilmiah Pariwisata Vol. 2 No. $1 \mathrm{Hal}$ 109-222.

Kuswara. 2007. Arahan Pengembangan Permukiman di Kawasan Daerah Tangkapan Air Danau Toba. Jurnal Permukiman Vol. 2 No. 1 Hal 1-11.

Nugroho A. A. 2009. Pengaruh Kemacetan Lalu Lintas terhadap Perkembangan Kepariwisataan Kota Bandung (Studi Kasus: Kawasan Wisata Riau, Cihampelas, Alun-Alun dan Kebon Binatang) Tugas Akhir. Bandung: Jurusan Perencanaan Wilayah Kota. Institut Teknologi Bandung.

Peraturan Pemerintah Republik Indonesia Nomor 50 Tahun 2011 tentang Rencana Induk Pengembangan Pembangunan Kepariwisataan Nasional. Tambahan Lembaran Negara Republik Indonesia Nomor 5262. Jakarta.

Peraturan Presiden Republik Indonesia Nomor 81 Tahun 2014 tentang Rencana Tata Ruang Kawasan Danau Toba dan Sekitarnya. Lembaran Negara Republik Indonesia Tahun 2014 Nomor 191. Jakarta.

Rachman, A. 2011. Arahan Pengembangan Pariwisata di Satuan Kawasan Wisata Talaga Kabupaten Majalengka Berdasarkan Aspek Sediaan. Skripsi. Bandung: Universitas Pasundan.

Rusnanda, R. 2015. Kajian Potensi Wisata Kota Tapaktuan, Berbasis Masyarakat Lokal. Tugas Akhir, Medan: Program Studi Arsitektur Universitas Sumatera Utara.

Sianturi, T. 2004. Degradasi Danau Toba. Jurnal Penelitian Bidang Ilmu Pertanian Vol 2. No 1. Hal 1-3

Sudana, I.P 2013. Strategi Pengembangan Desa Wisata Ekologis di Desa Belimbing, Kecapatan Pupuan Kabupaten Tabanan. Jurnal Analis Pariwisata Vol 13. No. 1 Hal 11- 31

Teguh, F. 2015. Tata Kelola Destinasi Membangun Ekosistem Pariwisata. Gajah Mada University Press. Yogyakarta.

Undang-Undang Republik Indonesia Nomor 10 Tahun 2009 tentang Kepariwisataan. Lembaran Negara Republik Indonesia Tahun 2009 Nomor 11. Jakarta.

Wardianto. 2011. Perencanaan dan Pengembangan Pariwisata. Bandung: Lubuk Agung. 